\title{
Analisis Penjalaran Run-Up Gelombang Tsunami Menggunakan Pemodelan Numerik 2D di Pesisir Kota Bengkulu
}

\author{
Geby Ayunda ${ }^{1}$, Aris Ismanto ${ }^{1}$, Hariyadi ${ }^{1}$, Denny Nugroho Sugianto ${ }^{1}$ \\ dan Muhammad Helmi ${ }^{1}$ \\ ${ }^{1}$ Departemen Oseanografi, Fakultas Perikanan dan Ilmu Kelautan, Universitas Diponegoro \\ Jalan Prof. H. Soedarto, S.H., Tembalang, Semarang. 50275 \\ Email: gebyayunda18@gmail.com
}

\begin{abstract}
Abstrak
Indonesia terletak pada pertemuan tiga lempeng utama yaitu lempeng India-Australia, lempeng Pasifik dan lempeng Eurasia. Dari aktifitas lempeng-lempeng tersebut menjadikan Indonesia rawan akan gempa bumi. Salah satu wilayah yang rentan terhadap bencana gempa bumi adalah provinsi Bengkulu. Wilayah pesisir barat Bengkulu berbentuk teluk dan pantai yang landai, apabila terjadi gempa bumi besar maka wilayah tersebut berpotensi dilanda gelombang tsunami dengan tingkat kerusakan yang tinggi. Tujuan dari penelitian ini adalah memperkirakan waktu tempuh tsunami, menentukan tinggi (run-up) dan sebaran jangkauan tsunami di pesisir Pantai Bengkulu. Metode penelitian yang digunakan adalah kuantitatif dengan menggunakan data batimetri, titik tinggi, parameter gempa, topografi daratan dan peramalan pasang surut wilayah perairan kota Bengkulu. Pemodelan tsunami menggunakan software COMCOT versi 1.7. Berdasarkan pengolahan data, diketahui bahwa waktu tempuh gelombang dari pusat pembangkit tsunami sampai dengan pantai berkisar 36 menit dengan ketinggian run-up mencapai 2,59 meter. Gelombang tsunami tertinggi terjadi di titik pengukuran 5 karena terdapat pengaruh kondisi topografi yang landai sehingga energi gelombang yang dibawa tinggi. Wilayah jangkauan gelombang tsunami terluas berada pada ketinggian run-up 0,1 - 3,4 m dengan luas 40,101 $\mathrm{km}^{2}$, ketinggian run-up 3,4-6,8 seluas $1,601 \mathrm{~km}^{2}$, dan ketinggian run-up 6,8-10,2 seluas $0,494 \mathrm{~km}^{2}$. Berdasarkan hasil validasi dengan menggunakan nilai RSR diperoleh sebesar 0,17 yang masuk dalam kriteria sangat baik.
\end{abstract}

Kata Kunci: Tsunami, Daerah Jangkauan, Pemodelan Numerik, Comcot

\begin{abstract}
Indonesia is located at the confluence of three main plates namely the India-Australia plate, the Pacific plate and the Eurasian plate. The activity of these plates, makes Indonesia prone to earthquakes. One area that is vulnerable to earthquake disasters is Bengkulu province. The west coast of Bengkulu is in the form of gulfs and gently sloping beaches. In the event of a large earthquake, the area is potentially to be hit by a tsunami wave with a high level of damage. The purpose of this study is to estimate the tsunami travel time, determine the height (run-up) and the distribution of tsunami coverage on the coast of Bengkulu Beach. The research method used is quantitative by using bathymetry data, high points, earthquake parameters, land topography and tidal forecasts of Bengkulu city waters. Tsunami modeling using COMCOT software version 1.7. Based on data processing, it is known that the travel time of waves from the tsunami generating center to the coast is around 36 minutes with a run-up height of 2.59 meters. The highest tsunami wave occurs at measurement point 5 because there is an influence of the sloping topographic conditions so that the wave energy carried is high. The widest range of tsunami waves is at the run-up height of 0.1 $3.4 \mathrm{~m}$ with an area of $40.101 \mathrm{~km}^{2}$, the run-up height of $3.4-6.8$ covering an area of $1.601 \mathrm{~km}^{2}$, and the run-up height of $6.8-10.2$ covering an area of $0.494 \mathrm{~km}^{2}$. Based on the results of the validation using the RSR value obtained by 0.17 which is included in the criteria very well.
\end{abstract}

Keywords: Tsunami, Reach Areas, Numeric Modeling, Comcot

http://ejournal2.undip.ac.id/index.php/ijoice/

Diterima/Received : 27-06-2020

Disetujui/Accepted : 31-10-2020 


\section{PENDAHULUAN}

Indonesia menempati zona tektonik yang sangat aktif karena berada di tiga lempeng besar dunia yang saling bertemu dan membentuk jalur-jalur pertemuan lempeng yang kompleks. Keberadaan interaksi antar lempeng-lempeng tektonik ini menempatkan wilayah Indonesia sebagai wilayah yang sangat rawan akan bencana, letusan gunung api dan tsunami. Kejadian gempa yang terjadi didekat batas pertemuan antara lempeng samudra yang menunjam masuk ke bawah lempeng benua diklasifikasikan sebagai zona subduksi. Zona subduksi merupakan wilayah yang sering melepaskan energi gempa bumi yang dapat membangkitkan gelombang tsunami (Salim dan Santosa, 2014).

Pulau Sumatera merupakan salah satu wilayah yang memiliki tatanan tektonik yang cukup unik. Hal ini dikarenakan pulau Sumatera memiliki dua kondisi geologi yang dapat mempengaruhi aktivitas seismik dan kondisi tektonik pulau Sumatera. Hal ini karena terdapat dua zona subduksi. Pertama, zona subduksi yang berada di batas antar lempeng India-Australia yang menunjam ke dalam lempeng Eurasia. Zona ini berpotensi menimbulkan gempa bumi dengan magnitudo relatif lebih besar sehingga sangat mungkin bisa menimbulkan tsunami. Kedua, zona sesar Sumatera yang juga dikenal sebagai sesar Semangko atau Sumateran Fault Zone (SFZ). Zona ini membentang di darat pulau Sumatera yang membelah pulau Sumatera menjadi dua, yang membentang sepanjang pegunungan Bukit Barisan, dari laut Andaman sampai ke Teluk Semangko. Sehingga kedua zona inilah yang menyebabkan pulau Sumatera sangat rawan terhadap bencana gempa bumi dan tsunami (Asnita et al., 2016),

Wilayah barat pulau Sumatera merupakan satu kawasan yang terletak pada pinggiran lempeng aktif dunia yang dicerminkan dengan tingginya frekuensi kejadian gempa bumi di wilayah ini. Sebaran gempa bumi di wilayah ini tidak hanya bersumber dari aktivitas zona subduksi, tetapi juga dari sistem sesar aktif di sepanjang pulau Sumatera. Zona subduksi di Pulau Sumatera merupakan pertemuan lempeng tektonik yang paling sering melepaskan energi (Setyonegoro et al., 2012).

Berdasarkan catatan sejarah gempa bumi di wilayah barat pulau Sumatera, yakni Bengkulu memiliki potensi gempa bumi besar dan dapat membangkitkan gelombang tsunami. Wilayah Bengkulu dan sekitarnya masih memiliki akumulasi stress yang tinggi setelah kejadian gempa bumi 4 Juni 2000 dan 12 September 2007 (Ardiansyah, 2014). Wilayah Bengkulu khususnya di wilayah rupture zone gempa bumi 12 September 2007 memiliki tingkat kerapuhan batuan yang rendah dan berpeluang terjadinya gempa bumi besar di waktu yang akan datang. Wilayah pesisir barat Bengkulu berbentuk teluk dan pantai yang landai, apabila terjadi gempa bumi besar maka wilayah tersebut berpotensi dilanda gelombang tsunami dengan tingkat kerusakan yang tinggi (Pujiastuti et al., 2007).

Proses terjadinya gempa bumi dari dasar laut merupakan dasar permodelan sumber (source) tsunami yang menunjukkan pergeseran dasar laut secara vertikal. Permodelan source tsunami diperlukan untuk membuat permodelan penjalaran serta jangkauan tsunami. Maka penelitian ini akan lebih difokuskan untuk membuat permodelan numerik tsunami yang dibangkitkan oleh gempa bumi di wilayah barat Pulau Sumatra yakni pada wilayah pesisir Kota Bengkulu dengan memperhatikan efek terhadap besaran (magnitude) gempa yang ditimbulkan. Dengan penelitian ini, maka dapat mengetahui karakteristik gelombang tsunami dan luas daerah jangkauan tsunami sebagai dampak akibat tsunami ke daerah pantai yang berada di pesisir Kota Bengkulu.

\section{Materi dan Metode \\ Materi Penelitian}

Materi penelitian ini menggunakan data utama dan data pendukung. Data utama yang digunakan meliputi 1) Data batimetri GEBCO skala 30 arc second publikasi BODC; 2) Data BATNAS perairan Kota Bengkulu skala 6 arc second publikasi BIG;3) Data historis gempa dan parameter gempa yang diperoleh dari USGS. Sedangkan data pendukung yang digunakan meliputi 1) Peta Rupabumi Indonesia Kota Bengkulu tahun 2018 publikasi BIG; 2) Data DEMNAS wilayah Kota Bengkulu publikasi BIG; 3) Data digital pasang surut BIG bulan September 2019. 


\section{Metode Penelitian}

Penelitian ini menggunakan metode kuantitatif. Menurut Sugiyono (2013), metode penelitian kuantitatif merupakan metode statistik untuk menganalisis data dengan cara membuat gambaran mengenai situasi atau kejadian yang diteliti pada waktu dan tempat tertentu yang telah terkumpul. Pada penelitian ini, pemodelan tsunami menggunakan simulasi numerik menggunakan perangkat lunak COMCOT v1.7, kemudian hasilnya dianalisis untuk mengetahui daerah jangkauan tsunami di pesisir Kota Bengkulu.

\section{Metode Pengolahan Data}

Pengolahan data yang dilakukan pada penelitian ini terdiri dari tahap persiapan data, proses pemodelan tsunami dan daerah jangkauan tsunami. Persiapan data yaitu dilakukan proses pengolahan data batimetri, data titik tinggi, data parameter gempa, data pasang surut, titik lokasi pengamatan. Data batimetri dan titik tinggi diekspor kedalam format xyz. Pada Penelitian ini menggunakan 2 layer dengan ukuran grid yang berbeda yaitu 01 dan 02 sebagai kode masukan.

Tabel 1. Batas Boundary Model dan Ukuran Grid

\begin{tabular}{cccc}
\hline Layer & Lintang & Bujur & Ukuran Grid $\left(\mathrm{km}^{2}\right)$ \\
\hline 1 & $-7.36606^{\circ}-5.86615^{\circ}$ & $91.82416^{\circ}-105.93978^{\circ}$ & $2,326,329$ \\
2 & $-3.37203^{\circ}--4.30518^{\circ}$ & $101.23003^{\circ}-102.58293^{\circ}$ & 22,467 \\
\hline
\end{tabular}

Data parameter gempa yang digunakan sebagai masukan pada COMCOT v 1.7 adalah data kejadian gempa Bengkulu 12 September 2007. Data parameter gempa yang telah dimodelkan (Pujiastuti et al., 2016). Berikut data sumber Gempa 12 September 2007 yang diperoleh dari BMKG dan USGS.

Tabel 2. Parameter Gempa

\begin{tabular}{|c|c|c|c|c|c|c|}
\hline \multirow{2}{*}{ Magnitudo } & \multicolumn{2}{|c|}{ Epicenter } & \multirow{2}{*}{$\begin{array}{c}\text { Depth } \\
(\mathrm{km})\end{array}$} & \multirow{2}{*}{$\begin{array}{l}\text { Strike } \\
\left({ }^{\circ}\right)\end{array}$} & \multirow{2}{*}{$\begin{array}{l}\text { Dip } \\
\left(^{\circ}\right)\end{array}$} & \multirow{2}{*}{$\begin{array}{c}\text { Slip } \\
\left(^{\circ}\right)\end{array}$} \\
\hline & Longitude & Latitude & & & & \\
\hline $8.4 \mathrm{Mw}$ & 101.367 & -4.438 & 10.0 & 327 & 12 & 114 \\
\hline
\end{tabular}

Proses pemodelan dimulai dengan melakukan input data model yang meliputi data batimetri, koordinat lokasi pengukuran tinggi tsunami, dan historis gempa. Simulasi dijalankan dengan total durasi waktu 2,5 jam setelah terjadi gempa. Melalui proses tersebut akan dihasilkan data kondisi awal tsunami dan tinggi gelombang tsunami secara time series pada koordinat titik pengamatan. Titik ini diposisikan di perairan Barat Sumatera Provinsi Bengkulu yang mengarah ke Timur Laut kota Bengkulu dan terdiri dari lima titik pengamatan. Penentuan titik berdasar kepada arah datangnya gelombang menuju pesisir pantai. Data ketinggian air akan tercatat pada titik pengukuran virtual yang di input melalui data "ts_location.dat" pada Comcot yang dapat dilihat pada Tabel 3.

Tabel 3. Koordinat Titik Pengamatan Ketinggian Gelombang Tsunami

\begin{tabular}{ccc}
\hline Titik & Bujur & Lintang \\
\hline Ts_location 1 & 101.580463 & -4.317407 \\
Ts_location 2 & 101.785453 & -4.177143 \\
Ts_location 3 & 101.981458 & -4.055687 \\
Ts_location 4 & 102.136107 & -3.949367 \\
Ts_location 5 & 102.282994 & -3.858520 \\
\hline
\end{tabular}


Distribusi tinggi maksimum tsunami merupakan sebaran tinggi amplitudo maksimum gelombang tsunami pada daerah penelitian. Pengolahan data pada pemodelan akan menghasilkan data "zmax_layerxx" dimana "xx" menunjukkan kode layer.

Proses pengolahan daerah jangkauan tsunami, diperlukan pengolahan pada data "zmax_layerxx.dat" sebagai output model dan data peramalan pasang surut. Data pasang surut diolah dengan menggunakan metode World Tide Analysis untuk menghasilkan nilai MSL sebagai input data pada model. Hasil data "zmax_layerxx.dat" dan data MSL diolah menjadi data flowdepth yang menggambarkan daerah jangkauan tsunami. Data flowdepth dilakukan interpolasi untuk mendapatkan interpretasi daerah jangkauan tsunami yang kemudian dilakukan overlay dengan peta penggunaan lahan pada Peta Rupa Bumi Indonesia. Perhitungan luas daerah jangkauan, dilakukan menggunakan fungsi calculate geometry.

\section{HASIL DAN PEMBAHASAN}

Gempa yang terjadi pada episenter -4.438 LS dan 101.367 BT dengan kekuatan 8,4 Mw, menghasilkan kondisi awal laut saat terjadi gempa seperti pada Gambar 1. Hasil kondisi awal tersebut nilai elevasi permukaan tertinggi zmax sebesar $7,38 \mathrm{~m}$, elevasi permukaan terendah zmin sebesar $-3,90$ $\mathrm{m}$, dan kecepatan gelombang cmax sebesar $7,01 \mathrm{~m} / \mathrm{s}$.

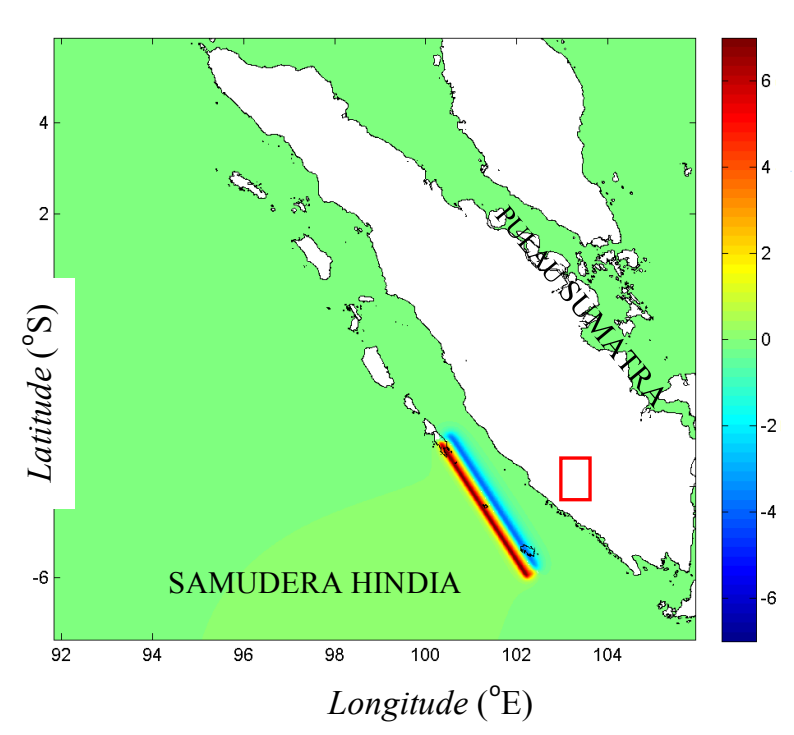

Gambar 1. Kondisi Awal Tsunami sesaat pasca Terjadi Gempa

Pemodelan tsunami ini menghasilkan pergerakan muka air laut yang berlangsung dengan durasi 2,5 jam (9000 detik). Melalui hasil penelitian, diketahui kondisi laut di sekitar pusat gempa bergantung pada pembangkit atau hiposentrum gempa dan pergeseran lempeng yang dapat menyebabkan terjadinya kenaikan dan penurunan muka air laut. Menurut Triatmadja (2010), daerah yang berdekatan dengan sumber - sumber gempa laut (patahan), dasar lautan sebagian akan terangkat (uplifted) secara permanen dan sebagian lagi turun ke bawah (down-dropped), sehingga mendorong gerakan kolom air naik dan turun.

Ts_location merupakan titik pengamatan virtual yang di input pada data_proc.m pada pengolahan data. Melalui data titik pengamatan, didapatkan data time series tinggi gelombang tsunami sebagai berikut : 
Tabel 4. Waktu Tempuh Tsunami dan Ketinggian Tsunami Maksimum

\begin{tabular}{cccccc}
\hline Titik Pengukuran & \multicolumn{2}{c}{ Koordinat } & & $\begin{array}{c}\text { Waktu Zmax } \\
\text { (jam:menit:detik) }\end{array}$ & $\begin{array}{c}\text { Zmax } \\
(\mathrm{m})\end{array}$ \\
\cline { 2 - 3 } & Bujur & Lintang & & $00: 21: 18$ & 1,02 \\
Ts_location1 & 101.580463 & -4.317407 & & $00: 24: 04$ & 1,13 \\
Ts_location2 & 101.785453 & -4.177143 & & $00: 18: 29$ & 1,58 \\
Ts_location3 & 101.981458 & -4.055687 & & $00: 35: 11$ & 2,23 \\
Ts_location4 & 102.136107 & -3.949367 & & $00: 56: 16$ & 4,9 \\
Ts_location5 & 102.296858 & -3.889649 & &
\end{tabular}

Sumber : (Pengolahan Data, 2020)

Keterangan :

Zmax : Tinggi gelombang tsunami maksimum terhadap MSL

Waktu Zmax : Waktu saat terjadi gelombang maksimum

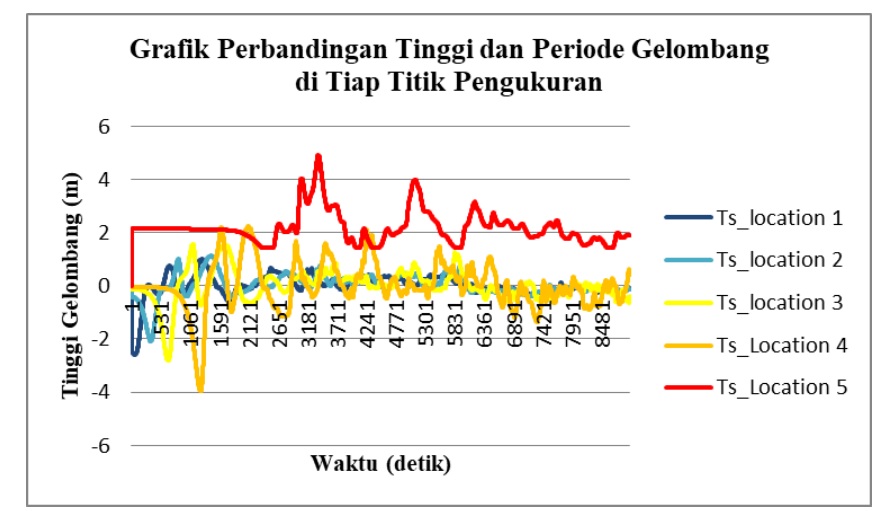

Gambar 2. Grafik Perbandingan Tinggi dan Periode Gelombang Tsunami di Setiap Titik Ts_location (Pengolahan Data, 2020).

Hasil visualisasi diketahui bahwa penjalaran gelombang tsunami setelah terjadinya gempa dengan magnitudo yang besar maka sebagian besar gelombang merapat ke arah pantai dan sebagian lagi menyebar ke laut lepas. Penjalaran gelombang tsunami ini diawali dengan kondisi surut yang terjadi di sepanjang pantai pada menit ke -28 kemudian disusul gelombang pada menit ke -31 . Gelombang tiba di pesisir Kota Bengkulu pada menit ke -36 dengan penjalaran yang rapat gelombang tsunami telah tiba di pesisir Kota Bengkulu dan sebagian lagi menuju laut lepas. Hal ini menunjukkan bahwa terjadi proses difraksi dan refleksi gelombang yang menyebabkan sebagian gelombang yang menjalar kemudian merenggang mengarah ke laut lepas dan sebagian lagi mengarah pesisir Kota Bengkulu.

Waktu penjalaran ini dapat dipengaruhi oleh beberapa faktor salah satunya pada nilai parameter sesar yaitu strike, dip dan slip. Berdasarkan data yang digunakan, masing-masing nilai parameter sesar diantara nya adalah strike $=327^{\circ}$, dip $=12^{\circ}$ dan slip $=114^{\circ}$. Hasil dari pengolahan data, diketahui nilai strike/arah bidang sesar sejajar dengan pulau Pagai Selatan dan pulau Enggano dan pulau Enggano merupakan wilayah yang lebih cepat terkena gelombang tsunami. Hal ini didasarkan sesuai satuan sudut derajat kompas dan arah mata angin, bahwa nilai strike mengarah dari Barat Laut ke Tenggara sehingga menghasilkan arah penjalaran gelombang dari sumber gempa menuju Timur pesisir Bengkulu kemudian menyebar ke arah Tenggara, Selatan, Barat Daya, Barat, Barat Laut, Utara hingga Timur Laut.

Distribusi amplitudo maksimum tsunami dapat menggambarkan sebaran dampak dan pola pergerakan gelombang tsunami dari pusat gempa sampai daratan. Hasil distribusi amplitudo 
maksimum tsunami di wilayah pesisir Kota Bengkulu dapat dilihat pada Gambar 3b, diketahui dominan memiliki tinggi gelombang mencapai 5 meter. Secara vertikal distribusi amplitudo maksimum tsunami dari pusat gempa sampai pesisir dapat dilihat pada Gambar 4. Distribusi tinggi maksimum gelombang tsunami pada titik pengamatan ts_location 5 menghasilkan nilai distribusi maksimum tertinggi dibandingkan titik lainnya.

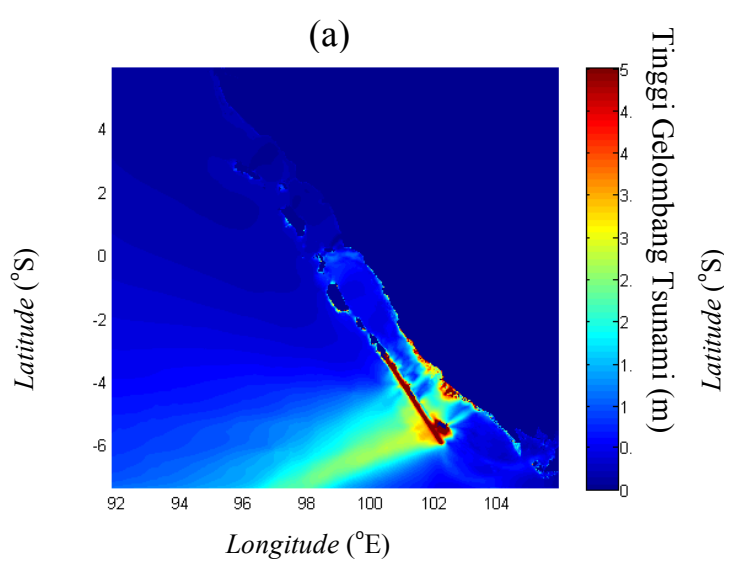

(b)

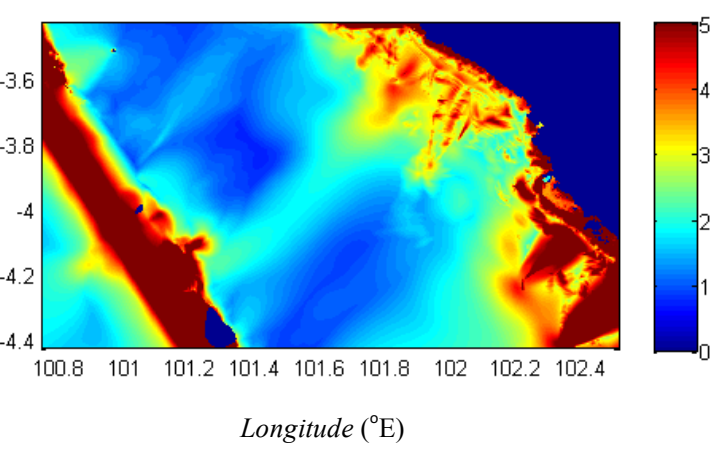

Gambar 3. Distribusi Zmax (a) Layer 01; dan (b) Layer 02

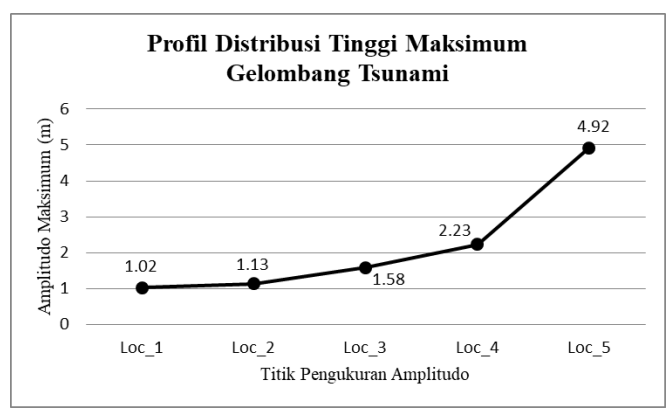

Gambar 4. Grafik Amplitudo Maksimum Gelombang Tsunami

Data hasil model selanjutnya di validasi dengan data hasil penelitian yang dilakukan oleh Pujiastuti et al (2016) yang dikombinasikan dengan data observasi lapangan yang telah dilakukan oleh Badan Meteorologi, Klimatologi dan Geofisika. Perhitungan run-up menggunakan Data Survei Lapangan ditunjukan pada Tabel 5 sebagai berikut :

Tabel 5. Perhitungan Verifikasi Run-Up

\begin{tabular}{|c|c|c|c|c|c|}
\hline \multicolumn{2}{|c|}{ Koordinat } & \multirow{2}{*}{$R$} & \multirow{2}{*}{$\mathrm{RM}$} & \multirow{2}{*}{$(\mathrm{R}-\mathrm{Rm})^{2}$} & \multirow{2}{*}{$\left(\mathrm{R}-\sum \mathrm{R}\right)^{2}$} \\
\hline Bujur & Lintang & & & & \\
\hline 109.815 & -7.382 & 2,35 & 2,59 & 0,0576 & 1,8225 \\
\hline \multicolumn{2}{|r|}{ Jumlah } & & 1 & 0,0576 & 1,8225 \\
\hline \multicolumn{2}{|c|}{$\sigma D$} & & 1,35 & & \\
\hline \multicolumn{2}{|c|}{ RMSE } & & 0,24 & & \\
\hline \multicolumn{2}{|c|}{ RSR } & & 0,17 & & \\
\hline
\end{tabular}

Keterangan :

$\mathrm{R} \quad=$ Tinggi run-up hasil survei dan penelitian (m)

$\mathrm{RM} \quad=$ Tinggi Run-up model (m)

RMSE $=$ Root Mean Square Error 
$\sigma D$ $=$ Standar Deviasi

Nilai pada Tabel 5, dijabarkan untuk perhitungan verifikasi dan validasi dengan metode RSR sebagai berikut :

$\sigma D=\sqrt{\frac{\left(\mathrm{R}-\sum \mathrm{R}\right)^{2}}{n}}=\sqrt{\frac{1.8225}{1}}=1,35$

$\mathrm{RMSE}=\sqrt{\frac{(\mathrm{R}-\mathrm{M})^{2}}{n}}=\sqrt{\frac{10,0576}{1}}=0,24$

$\mathrm{RSR}=\frac{R M S E}{\sigma D}=\frac{1,32}{0,24}=0,17$

Tsunami mengalami proses penjalaran menuju pantai, dan akan mengalami run up. Gambar 5 merupakan hasil pengolahan data tinggi run up di darat dan luas daerah jangkauan tsunami dari garis pantai. Berdasarkan pengolahan data, didapatkan hasil nilai tinggi run-up maksimum mencapai 10,2 $\mathrm{m}$.

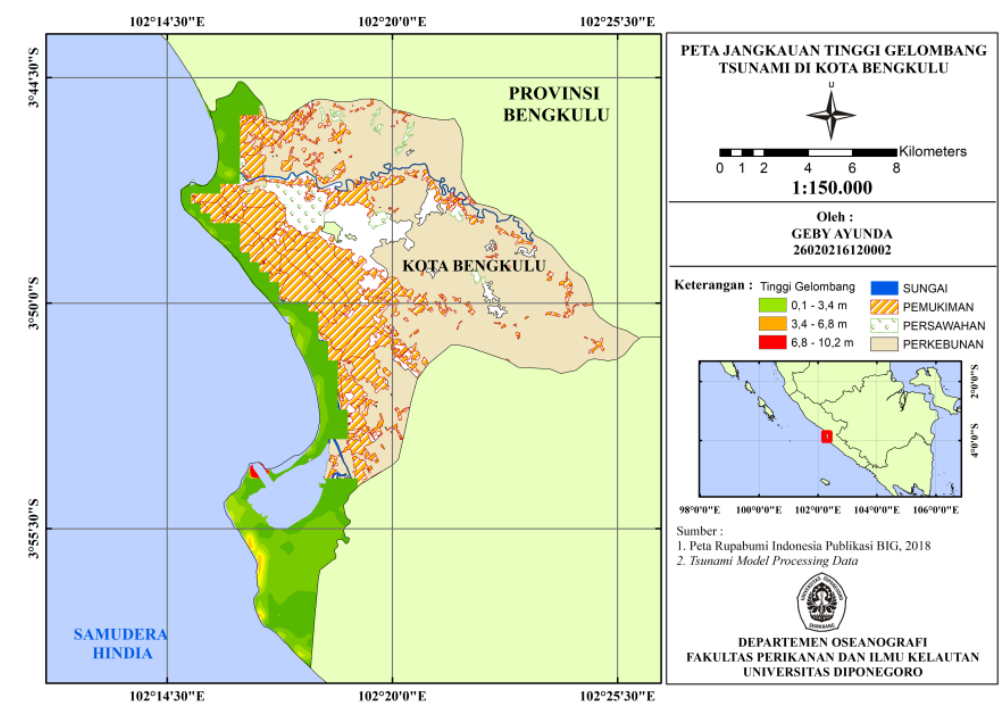

Gambar 5. Peta Daerah Jangkauan dan Tinggi Genangan Tsunami pada Skenario Gempa 8,4 $\mathrm{Mw}$

Pengolahan data yang telah dilakukan, dihasilkan luas daerah jangkauan berbeda yang ditinjau berdasarkan ketinggian gelombang. Pada peta jangkauan (Gambar 5) diperoleh hasil luas daerah jangkauan tsunami di Kota Bengkulu seluas $40,101 \mathrm{~km}^{2}$ pada ketinggian run-up 0,1 - 3,4 m yang ditunjukkan dengan warna hijau, kemudian seluas $1,601 \mathrm{~km}^{2}$ pada ketinggian run-up 3,4-6,8 $\mathrm{m}$ yang ditunjukkan dengan warna oranye, dan sejauh $0,494 \mathrm{~km}^{2}$ pada ketinggian run-up $6,8-10,2 \mathrm{~m}$ yang ditunjukkan dengan warna merah. Ketinggian suatu wilayah dan kelerengan pantai cukup signifikan mempengaruhi luas daerah jangkauan tsunami. Semakin rendah posisi suatu wilayah maka akan semakin besar potensi wilayah tersebut akan terdampak oleh tsunami, sedangkan kelerengan akan berpengaruh terhadap jarak tempuh gelombang tsunami di daratan.

Pada daerah penelitian terdapat teluk yang terletak berhadapan dengan Samudera Hindia. Keberadaan teluk ini tentu mempengaruhi jangkauan gelombang yang sampai di pesisir. Peta jangkauan pada wilayah terdampak tsunami menunjukkan daerah yang paling luas berada di daerah teluk sampai selatan Kota Bengkulu dengan ketinggian run up mencapai 3 meter dan di dominasi ketinggian mencapai 6,8 meter di pesisir selatan Kota Bengkulu. Pada bibir teluk, ketinggian run up mencapai 10 meter. Menurut Aperus et al., (2016), daerah berbentuk teluk ini menyebabkan sifat 
gelombang tsunami menjadi kuat, saling terpantul dan terinterferensi (tergabung) menjadi gelombang yang besar sehingga kekuatan gelombang akan terfokus pada teluk tersebut. Akibatnya daerah di sekitar teluk terkena limpasan gelombang yang lebih besar dibandingkan dengan pantai yang relatif datar disepanjang pesisir utara Kota Bengkulu.

\section{KESIMPULAN}

Berdasarkan hasil penelitian di Pesisir Kota Bengkulu diperoleh kesimpulan sebagai berikut :

1. Penjalaran tsunami diawali dengan kondisi surut di sepanjang pantai pada menit ke-28 dan disusul gelombang tsunami pada menit ke-31. Waktu tempuh yang dibutuhkan gelombang tsunami dari pusat pembangkit tsunami (epicenter) sampai pesisir Bengkulu yaitu berkisar 36 menit dan menghasilkan ketinggian run-up mencapai 2,59 meter.

2. Luas daerah jangkauan tsunami yang dihasilkan di Kota Bengkulu seluas $40,101 \mathrm{~km}^{2}$ pada ketinggian run-up berkisar $0,1-3,4 \mathrm{~m}$, seluas $1,601 \mathrm{~km}^{2}$ pada ketinggian run-up berkisar 3,4$6,8 \mathrm{~m}$, dan seluas $0,494 \mathrm{~km}^{2}$ pada ketinggian run-up berkisar $6,8-10,2 \mathrm{~m}$ pada daerah jangkauan. Sebagian besar tergenang merupakan wilayah pemukiman masyarakat.

\section{DAFTAR PUSTAKA}

Asnita, W., D. Sugiyanto, I. Rusydy. 2016. Kajian Statistik Seismisitas Kawasan Sumatera. Jurnal Natural, 16(2).

Aperus, R. D. Pujiastuti., R. Billiyanto. 2016. Pemodelan Tinggi dan Waktu Tempuh Gelombang Tsunami Berdasarkan Data Historis Gempa Bumi Bengkulu 4 Juni 2000 di Pesisir Pantai Bengkulu. Jurnal Fisika Unand, 5(4).

Pujiastuti, D., R. Aperus, R. Billyanto. 2016. Analisis Pemodelan Tinggi dan Waktu Tempuh Gelombang Tsunami di Pesisir Pantai Bengkulu dengan Menggunakan Data Historis Gempa Bengkulu 12 september 2007. Prosiding SNFA (Seminar Nasional Fisika dan Aplikasinya). Pascasarjana Ilmu Fisika, Universitas Sebelas Maret Surakarta.

Salim, R., B. J. Santosa. 2014. Analisa Pola Bidang Sesar pada Zona Subduksi di Wilayah Selatan Pulau Sumatera dari Event Gempa pada Tahun 2011 - 2014. Jurnal Teknik Pomits, 3(2):23019271.

Sugiyono. 2009. Metode Penelitian Kuantitatif, Kualitatif dan R\&D. ALFABETA. Bandung

Setyonegoro, W. 2009. Tsunami Numerical Simulation Applied to Tsunami Early Warning System Along Sumatra Region. JICA Training Course.

Triatmadja, R. 2010. Tsunami Kejadian, Penjalaran, Daya Rusak, dan Mitigasinya. Gadjah Mada University Press. Yogyakarta. 